\title{
Left Out
}

\section{Policy Diffusion and the Exclusion of Black Workers from Unemployment Insurance}

\author{
Richard Rodems and H. Luke Shaefer
}

\begin{abstract}
Social scientists and historians have identified the exclusion of agricultural workers and domestic servants from social insurance programs during the New Deal as a cause of the racially divided US welfare state. The most prominent explanation for these exclusions is that they originated in a Southern-dominated congress and were deliberately designed to exclude a majority of African-American workers from the emerging welfare state. This article examines recent historical scholarship, archival evidence, and information on unemployment compensation programs internationally to situate this policy choice in a wider context. The exclusion of these categories of workers is consistent with the experience of other unemployment insurance programs. Given the close linkages between the technical experts who drafted the US legislation and their counterparts abroad, the exclusion of agricultural workers and domestic servants from unemployment insurance is best understood as an example of policy diffusion.
\end{abstract}

\section{Introduction}

The 1935 Social Security Act (SSA) created the modern American welfare state. Despite President Roosevelt's intentions to create a comprehensive system of social insurance for all Americans, agricultural workers and domestic servants-a majority of the African-American workforce in 1935-were categorically excluded from the two key social insurance programs of the act: old age insurance (OAI, also often referred to as Social Security) and unemployment insurance (UI). This article examines current social scientific thinking regarding the origins of these exclusions and offers an alternative causal explanation: the categorical exclusion of these workers as a case of international policy diffusion.

Social scientists have understood these categorical exclusions as either racially motivated by Southern political interests, reflective of existing domestic programs that focused on urban industrial workers, or simply a result of administrative limitations of a new social program of unprecedented size. Yet while there was compelling evidence at the time that a more comprehensive system inclusive of domestic and agricultural workers could have been implemented at the start, such a stance would have put the United States out-of-line with comparable programs in other countries, all of which excluded domestic and agricultural workers when they were first implemented, a fact that the key New Deal policy makers were well aware of. To the authors' knowledge, the current analysis is the first to take the international context into account, and argue that it was primarily international isomorphic pressures that led to these exclusions, rather than domestic racial dynamics. 


\section{Background on Unemployment Insurance and the Social Security Act}

Over the course of the late nineteenth and early twentieth centuries, industrializing states began to develop various institutions to soften the blows of the industrial era and its related social problems. Unemployment compensation is a common program across industrialized welfare states aimed at both reducing the negative impact of involuntary unemployment on workers and their families and stabilizing the economy during economic retractions. Called UI in the United States, the 1935 SSA gave a broad framework in which each of the states could establish their own UI programs. Within a few years, all 48 states had functioning UI programs. UI is funded through taxes levied on employers based on workers' wages. Workers who apply and meet eligibility criteria are able to draw benefits for a specified duration.

The United States was relatively late in developing its UI system compared to other industrialized nations. During the 1910s and 1920s, there existed a handful of early private UI schemes in the United States run by welfare capitalist firms or individual unions. However, before the 1935 SSA required states to develop such programs, only Wisconsin succeeded in establishing a public system of unemployment compensation, in part due to the unique role of the Wisconsin Industrial Commission as a nexus of policy knowledge, political acumen, and administrative skill (Amenta et al. 1987; Blaustein, Cohen, and Haber 1993).

In 1934, President Roosevelt created the Committee on Economic Security (CES) and tasked it with drafting a comprehensive program of economic security for the United States. Chaired by Frances Perkins (secretary of labor), the executive committee also included Henry Morgenthau Jr. (secretary of the treasury), Homer Cummings (attorney general), Henry Wallace (secretary of agriculture), Harry Hopkins (federal emergency relief administrator and close advisor to FDR), and Professor Edwin Witte of the University of Wisconsin serving as executive staff director. Witte, a student of the famous institutional economist John R. Commons at the University of Wisconsin, had direct experience in building the nation's first UI program in Wisconsin.

Roosevelt's vision of an American welfare state was a broadly universal one, and the initial draft legislation the Roosevelt administration sent to Congress reflected this vision: agricultural and domestic workers were included in UI (Doughton 1935). Yet the version of the SSA passed by Congress and signed by FDR excluded these groups. How and why did agricultural workers and domestic servants become excluded from UI in the United States?

\section{Theories for the Exclusion}

What follows is an examination of three competing hypotheses presented by social scientists, historians, and social welfare experts for the exclusions of agricultural workers and domestic servants and the presentation of a competing hypothesis rooted in institutional analysis (table 1). 


\section{TABLE 1. Hypotheses examined}
Hypothesis
Claim

1. Racial Exclusion

2. The Wisconsin Group

3. Administrative Difficulty
Agricultural workers and domestic servants were excluded in order to exclude African-American workers from a key component of the New Deal.

A group of experts from the University of Wisconsin dominated the CES and pushed a vision of UI that was racially blind and oriented toward urban, industrial workers.

Agricultural workers and domestic servants were too administratively difficult to include in UI in 1935.

\section{Hypothesis 1: Racial Exclusions}

The racial bifurcation of the US welfare state into relatively popular and generous social insurance programs like OAI and UI aimed at white Americans and stigmatized, disciplinary, means-tested social assistance programs targeting African Americans such as Aid to Families with Dependent Children (AFDC, commonly referred to as welfare) has been a major site of scholarly research on the US welfare state (Amenta, Bonastia, and Caren 2001). One group of researchers, including Lieberman (1998) and Katznelson (2005), who build on the framework of sociologist Jill Quadagno $(1988,1996)$, view race as the primary factor involved in the exclusion of agricultural and domestic workers from both OAI and UI. Lieberman (1998: 25) writes that: "In order to pass national old-age and unemployment insurance plans, the Roosevelt administration had to compromise inclusiveness and accept the exclusion of agricultural and domestic employees from the program, with notably imbalanced racial consequences." It is precisely this insight-that the exclusions of these two categories of workers created a racially bifurcated welfare state - that makes the questions motivating this article interesting. However, as commonly proposed, this line of argument often depends on a unified Southern opposition in Congress as the source of the exclusion of agricultural workers and domestic servants.

The larger social context of the early New Deal was undeniably one in which race played a central role. Even if reformers had wanted to act legislatively to change the political, social, and economic oppression of American Americans, they would have run into a major roadblock according to these scholars: the "solid South." As it had been since the Civil War, the South was dominated by a one-party political system that tolerated some internal dissent but, at the federal level, exhibited a great deal of solidarity based on upholding a "coherent racial civilization, with a distinctive heritage, economy, social geography, and culture" (Katznelson 2005: 20). The seniority system in Congress ensured Southern power at the national level, providing long-serving Southerners a disproportionate number of committee chairmanships, and thus power over the entire legislative agenda.

According to scholars forwarding the racial exclusion hypothesis, Southern congressmen exerted their power on issues of race by excluding African Americans 
TABLE 2. Race and occupational exclusions

\begin{tabular}{lllll}
\hline Occupational Category & White & Black & Other & Total \\
& & & & \\
\hline Agriculture & $8,192,181$ & $1,987,839$ & 291,978 & $10,471,998$ \\
Domestic and personal service & $3,268,725$ & $1,576,205$ & 197,521 & $5,042,451$ \\
Total workers excluded from coverage & $11,460,906$ & $3,564,044$ & 489,499 & $15,514,449$ \\
Percentage of excluded workers & $74 \%$ & $23 \%$ & $3 \%$ & $100 \%$ \\
Total workers in all occupations & $42,584,497$ & $5,503,535$ & 741,888 & $48,829,920$ \\
Excluded workforce as a percentage of total workers & $27 \%$ & $65 \%$ & $66 \%$ & $31 \%$ \\
& & & & \\
\hline
\end{tabular}

Source: DeWitt 2010.

from the welfare state, albeit in indirect yet "racially laden" ways, as Lieberman (1998) puts it. These scholars view the exclusion of agricultural workers and domestic servants from UI as a convenient way of excluding blacks from the new systems of social security without making race explicit. Given the economic and demographic realities of the day, the result is indisputable: 65 percent of African Americans fell outside the reach of OAI and UI, up to 80 percent in some heavily black, agrarian parts of South. In contrast, 40 percent of whites nationally were also excluded due to the same categorical limitations. Despite the rapid industrialization of the early twentieth century, the United States was still a profoundly rural, agricultural society in 1935 (Katznelson 2005: 43). Table 2 presents the scope of the problem caused by these exclusions. This table is based on 1933 estimates from the Census Bureau as presented by DeWitt (2010) and shows even starker contrasts between black and white workers than the estimates provided by Katznelson.

While it is true that black workers were disproportionately likely to be excluded from coverage, they made up only about 23 percent of excluded workers. In fact, 11.5 million white workers were excluded, compared to 3.6 million black workers. If these exclusions were an indirect way to keep black workers from benefiting from a new social insurance system, they were a particularly blunt instrument for doing so, leaving behind nearly 30 percent of white workers.

More importantly, the legislative record forces a reconsideration of whether or not this serves as a sufficient explanation for why these workers were categorically excluded from UI. This is due to three reasons: (1) the image of a "Solid South" in Congress at this time is not entirely accurate; (2) many Southern politicians, in fact, wanted to see at least agricultural workers included; and (3) the final votes for the exclusions were bipartisan and multiregional.

Building on work by Davies and Derthick (1997), historian Mary Poole (2006) turns her attention to Congress and the theory of the "solid South." She concedes that the exclusions originated in Congress, which was dominated by Southerners, but a closer look at the positions of members of Congress in question reveals a more nuanced landscape. Drawing on V. O. Key's (1950) detailed analysis of Southern politics, Poole notes that Southern Democrats acted in concert against Northern Democrats 
only nine times between 1933 and 1949: five times to block antilynching legislation, twice against wage increases for the Works Progress Administration, once against an antidiscrimination provision in federal education financing, and once against a Fair Employment Practices measure. Southern Democrats failed to display their characteristic "solid" tendencies for the other 580 roll call votes (Key 1950: 346-52; Poole 2006: 35, 196n27). Julian Zelizer (2004: 23) concurs with this understanding of Southern legislators in the early New Deal: "As a whole, southern legislators were more liberal than northerners between 1933 and 1937. The one additional issue that tended to unite southern Democrats was the strong concern that federal funding should not be biased against their region. From a practical perspective, seniority and large Democratic majorities ensured that the most conservative chairs would continue to control committees."

Some Southern members of Congress actively argued against the exclusion of agricultural workers from UI. By exempting all agricultural workers, including a broad swath of white Southerners, Senator Connally (D-TX) expressed concern that the cost of UI would be borne by agricultural workers because the taxes necessary to fund the UI scheme would increase costs on "everything they consume, and they would get no benefit from it." Senator Hugo Black (D-AL) argued against the hybrid federal-state structure of the program out of concern that wealthier states would ultimately be able to fund their programs with lower tax rates thus drawing business from poorer states (Poole 2006: 42).

In summary, one would expect there to be something in the historical record suggesting explicit Southern support for the exclusion of agricultural and domestic workers from UI. While it is impossible to know what went unrecorded, occurred behind closed doors, or was simply taken as granted by the participants in these events, the available evidence suggests that this story does not explain how these exclusions came to pass. The words and actions of the main actors do not fit this hypothesis (DeWitt 2010). The consequence of these exclusions has been clear in that most African-American workers were left out of UI, but the cause of these exclusions does not appear to be entirely the result of the machinations of Southern congressmen.

\section{Hypothesis 2: The Wisconsin Group}

A second hypothesis, forwarded by Poole (2006), focuses on the fact that the exclusions of agricultural and domestic workers originated within the CES, despite the universalist goals of FDR. Poole argues that the staff of the CES, chosen by Secretary Perkins, was dominated by a group of economists and social welfare experts from Wisconsin, deeply influenced by John R. Commons, and administrative veterans of the only existent compulsory unemployment insurance scheme in North America. Poole identifies Edwin Witte of the CES as the "driving force behind adding the exclusion to the House bill." While not blatantly disagreeing with the president's universalist vision, Witte pointedly informed the congressional leaders that they "may deem it wise to exclude certain occupations" in the new social insurance programs (ibid., 39, 43). 
Evelyn Burns, an economist at Columbia University, member of the CES, and expert in social insurance programs commented "I do think that the staff on [the CES] did feel after a while that there was an effort to put everything into a box that was already a preconceived box, and substantially the box was something that the Wisconsin boys wanted, and that Miss Perkins wasn't going to buck the Wisconsin boys and Arthur Altmeyer, as chairman of the technical advisory committee wasn't going to buck Wisconsin. He was Wisconsin" (ibid., 92). The power and influence of the Wisconsin faction was recognized by other members of the CES.

\section{Hypothesis 3: Administrative Difficulties}

While Poole (2006: 80) makes a persuasive argument that "the Wisconsin agenda was the most influential factor in the construction of the Social Security Act as racially discriminatory," she shies away from the argument presented by members of the CES regarding these exclusions (Achenbaum 2007), namely that these economically marginalized groups were too administratively difficult to incorporate into UI from the start. Arthur J. Altmeyer, the head of the CES Technical Board, and later the head of the Social Security Board from 1937 to 1953, explained the technical difficulties regarding domestic workers (Altmeyer 1945a), "From the very beginning of the social security program, it has been recognized that domestic employees needed the protection of social insurance just as much as industrial and commercial employees. Because general administrative experience was lacking, however, special problems in including domestic employees seemed much more forbidding then than now." Rather than ignoring these workers or actively discriminating against them, the years after the passage of SSA were marked by active positions by many of the "Wisconsin boys" in favor or incorporation of these groups into the program (Altmeyer 1945b; Cohen 1940; Schlabach 1969).

The arguments made by members of the CES and other contemporary social insurance experts for the exclusions of domestic and agricultural workers can be boiled down to one key phrase: "administrative difficulties." Altmeyer (1945b) describes the problem in this way:

Workers engaged in purely agricultural pursuits were originally excluded in 1935 from both the old-age and the unemployment insurance programs because of the administrative difficulties involved in covering them, despite the knowledge that they were as much in need of protection as industrial and commercial employees. Collecting contributions and obtaining wage reports from numerous small employers unaccustomed to keeping records posed problems to which the answers were not then known. There was also the question whether to include or exclude wages "in kind" received by many farm workers. These administrative considerations were sufficiently strong to result in deferring the coverage of agricultural workers until experience had been gained in less difficult areas of coverage and techniques had been devised for meeting the special problems involved. 
One of the most outspoken and unyielding advocates of social insurance, Abraham Epstein of the American Association for Social Security, when speaking in front of the House Ways and Means Committee, was even more blunt (Epstein 1935):

Do not try to collect now from the farmers. Do not try to collect from the domestic servants. You cannot collect money from farmers. You cannot collect money from domestic servants. If you try to do that, you are going to have to spend more money in administering the act than you will ever collect. And when that leaks out they will come to me and say, "You are a hell of an advocate of social insurance. Look what you did; you made a mess of it." I am standing here before you, and I appeal to you, do not, for God's sake, ruin this legislation by overdoing it at first and undertaking things that you cannot possibly do.

You cannot make collections from farmers at this time. You cannot collect contributions from domestic servants. You cannot collect contributions from pushcart peddlers and small-store proprietors. It will cost you twice as much to collect as the amount of money that you will collect.

So, for God's sake, start mildly, start modestly. Let me tell you that no other country on earth-not only the big countries like ours, but other countries that are not spread out as ours are-no other country dared to try to include the agricultural workers and the domestic servants at first. And if that is so, why should you, with such an immense country like ours, with such a problem of administration to tackle, why should we undertake all these things and then fail in the administration of them so that it will all come back to us to plague us for the next generation.

I do not want to see that done. Include those employers from whom you can collect. You can collect from an employer of three or more people. That will not cost so much. But you cannot collect from farmers. You cannot collect from domestic servants. You cannot possibly do it.

The technical experts, including the Wisconsin-affiliated faction of the CES, were unanimous in their opposition to the inclusion of agricultural workers and domestic servants on the grounds that it was too administratively difficult to include them. What was the nature of this difficulty? The perception that these workers were too administratively difficult to include followed UI experts well into the late twentieth century. These labor markets were seen as inherently too unstable, too risky, for the underlying logic of UI (as opposed to need-based, noncontributory social assistance) to function (Blaustein and Craig 1977: 26-27). Even if it had been possible to administratively include these workers, it is possible that the unemployment risk of these workers would have made their participation actuarially unsound.

This claim that administrative difficulties alone made the inclusion of agricultural workers and domestic servants impossible is suspect due to two pieces of information. First, in 1936 the British extended their UI program to include a smaller, special scheme for agricultural workers (Burns 1941). Such inclusion was technically possible in the United Kingdom only a year after the debate and passage of the SSA. Second, the CES had assistance on this particular issue from two social insurance experts at 
the International Labor Office, Andre Tixier and Oswald Stein (Perkins 1946: 282). Their report in the Witte Archives presents a plan for a stamp-based system of administering UI. In this system, employees would have a passbook in which stamps were placed when employers made contributions to the UI system on their behalf. This simple administrative mechanism, which shifts the burden of record keeping from bureaucrats to workers, could be administered through post offices as it was in some European nations (Tixier and Davison 1936). This is precisely the solution to the "administrative difficulties" proposed ten years later by A. J. Altmeyer (1945a). Administrative difficulty was not administrative impossibility, although DeWitt (2010) contends that the stamp plan was not a fully satisfactory solution.

The overwhelming evidence from primary sources forces the consideration of this argument. It is clear that social insurance advocates and technical experts in the CES did not believe that the federal government had the administrative capacity to include agricultural workers and domestic servants from the start of any UI program. Where did they get this idea? Why do the very advocates of this program push for limited coverage? The answer is not to be found in Washington, but London, Berlin, and Madison, Wisconsin.

\section{Data and Methods}

Data for this article come from five sources: (1) the online archives of the Social Security Administration; (2) contemporary (early to mid-twentieth century) social scientific and social policy scholarship; (3) congressional testimony; (4) the Edwin Witte papers at the Wisconsin State Historical Society; and (5) the long-running series Social Security Programs throughout the World published since 1937 by the Social Security Administration and, since 2002, jointly with the International Social Security Association. The New Deal and the SSA are massive topics with voluminous scholarly histories (see Manza 2000). By taking a case-oriented approach, by focusing on one policy decision in one program, this article hopes to illuminate the action of one institutional mechanism at work in the creation of the US welfare state, albeit a mechanism whose action had profound ramifications for US society.

\section{An Alternative Explanation: International Policy Diffusion}

The British system of unemployment insurance has now been in effect for 24 years. I believe that their experience should be used by us in every way possible. -William Green (1935), President of the American Federation of Labor

In contrast to the three hypotheses presented in the preceding text, we present a fourth explanation for the exclusion of agricultural workers and domestic servants from UI: policy diffusion. While international comparisons in the study of welfare states and the systems of stratification they produce are common (see, e.g., Brady 2009; Esping- 
Andersen 1990), they have sometimes sidestepped the problem of policy diffusion in explaining international variation and similarity in welfare state programs (Goldthorpe 1997). Despite early steps in this direction (Abbott and DeViney 1992; Collier and Messick 1975), this literature seems to have picked up steam relatively recently (Hu and Manning 2010; Obinger, Schmitt, and Starke 2013) and is in conversation with a larger literature in public policy scholarship on policy diffusion and policy transfer (Benson and Jordan 2011; Dolowitz and Marsh 1996; Gilardi 2010).

Dobbin, Simmons, and Garrett (2007) identify four existing theoretical camps offering explanations of the policy diffusion process: (1) constructivist arguments that focus on the role of social norms, expert epistemic communities, and international organizations; (2) coercion theorists who identify powerful states as providing carrots and sticks for other states to adopt particular policies; (3) competition theorists who see states as adopting policies in order to attract investment; and (4) learning theorists who examine how states learn from their own policy experiences as well as those of other states. There is no evidence to suggest that the exclusion of agricultural workers and domestic servants was the result of external coercion or competition for foreign investment. Constructivist approaches illuminate additional social forces that have been otherwise hidden in the origins of these exclusions.

Constructivists have identified three mechanisms through which policy diffusion takes place: (1) leading nations serve as exemplars that other states copy; (2) expert groups facilitate diffusion across borders (an example of DiMaggio and Powell's [1983] normative isomorphism); and (3) policy makers and experts make judgments about appropriate policy based on the "psychological closeness" of states (e.g., Canada looking to the United Kingdom, Saudi Arabia looking to Syria). All of these mechanisms are at work in the exclusion of agricultural workers and domestic servants from UI.

The global spread of UI has received limited attention from scholars. $\mathrm{Hu}$ and Manning (2010) present a broad overview of social insurance as a global phenomenon while Kim $(2008,2010)$ and Harrington (1998) examine the conditions under which particular states adopt UI. Early US attempts at creating state-level UI programs are assessed by Amenta et al. (1987).

The United States was not the only nation to exclude agricultural workers and domestic servants from UI at the time of program inception. ${ }^{1}$ Table 3 lists the existing UI plans that the CES drew upon as they devised the contours of the UI program for the United States. Table 3 shows that not a single compulsory UI program prior to 1935 included agricultural workers and domestic workers when they were first established. ${ }^{2}$ If the United States was looking to other nations as exemplars, the first

1. Davies and Derthick (1997) also note that other states excluded these workers from social insurance programs, but their paper is primarily a study of OAI policy. This line of thought has also come under questioning for being descriptive rather than causal (Lieberman 2003).

2. The lack of variation in this regard does open up the possibility that the exclusion of these workers from UI programs is not just an example of policy diffusion, but of the performativity of policy norms within expert communities. 
TABLE 3. Unemployment insurance coverage as seen by the CES

\begin{tabular}{|c|c|c|c|c|}
\hline Nation or Subnational Unit & Year Introduced & Type of Program ${ }^{a}$ & $\begin{array}{l}\text { Selective or } \\
\text { Universal } \\
\text { Coverage }\end{array}$ & $\begin{array}{l}\text { Specific Exclusions for } \\
\text { Agricultural or } \\
\text { Domestic workers }\end{array}$ \\
\hline United Kingdom & 1911 & Compulsory UI & Selective & Both \\
\hline Ireland $^{\mathrm{b}}$ & $1911 / 1922$ & Compulsory UI & Selective & Both \\
\hline Italy & 1919 & Compulsory UI & Selective & Both \\
\hline Austria & 1920 & Compulsory UI & Selective & Both \\
\hline Queensland, Australia & 1922 & Compulsory UI & Selective & Agricultural workers ${ }^{\mathrm{c}}$ \\
\hline Poland & 1924 & Compulsory UI & Selective & Agricultural workers \\
\hline Bulgaria & 1925 & Compulsory UI & Selective & Domestic servants \\
\hline Germany & 1927 & Compulsory UI & Selective & Both \\
\hline Wisconsin, United States & 1932 & Compulsory UI & Selective & Both \\
\hline United States & 1935 & Compulsory UI & Selective & Both \\
\hline
\end{tabular}

Sources: Blaustein, Cohen, and Haber 1993; Committee on Economic Security 1937; and International Labour Office 1955.

${ }^{\text {a }}$ This table only includes information on compulsory unemployment insurance programs. Other programs, such as voluntary unemployment insurance programs (sometimes called the Ghent system, especially if administered through unions) and unemployment assistance programs (noncontributory, means-tested social assistance programs) tended to be more universal in their coverage but are not the relevant comparisons to the US example. Following Hu and Manning (2010), we also exclude unemployment insurance programs in state socialist societies that follow a different logic than Bismarkian social insurance. Following Stalin's example in 1930, it was common for state socialist governments to abandon unemployment insurance programs. For more on the abolition of the Soviet program, see Duranty (1930). ${ }^{\mathrm{b}}$ The Irish Free State inherited the UK system and continued to operate their UI system along these lines

${ }^{\mathrm{c}}$ The system in Queensland specifically included one type of agricultural worker: sugarcane workers. Due in part to the industrialized, nonseasonal nature of sugarcane production, such workers were early targets for inclusion in compulsory UI systems, such as those in Hawaii and Puerto Rico (Hitch 1958; Witte 1951).

mechanism of policy diffusion, this necessary precondition for the diffusion of these policies is met.

The second mechanism identified in the literature, the presence of expert groups facilitating diffusion across borders, or normative isomorphism, is the main mechanism through which these policy details diffused. How do we know that policy experts in the United States were taking their cues from the experiences of other nations? The centrality of the CES and the Wisconsin group in shaping the SSA has already been established by Poole (2006), but the larger context in which this group operated has been neglected. The social policy world of Madison, Wisconsin, was a key node in the pre-New Deal domestic social reform movements aimed at the state level (Amenta et al. 1987; Clemens 1997; Skocpol 1992). The Wisconsin group was part of an extensive transatlantic network of progressive social reformers (Rodgers 1998).

Rodgers (ibid., 414-39) sees the New Deal as a large exogenous shock to the hitherto rather stable field of social policy in the United States. When the crisis came, experts like Witte and Altmeyer were perfectly positioned to respond with "off the shelf" plans for complete social policies. "Only within the intellectual economy of catastrophe does the logic of the Social Security Act begin to fall into place. In the moment's hunger for solutions, social insurance came into the crisis premade and pretested, its arguments fully formed and elaborated" (ibid., 437). This is similar to Manza's (1995) understanding of the role of policy experts in the New Deal. 
The familiarity of the CES with European models of social insurance, including UI, is clear. The CES released a report titled "Social Security in America: The Factual Background of the Social Security Act as Summarized from Staff Reports to the Committee on Economic Security" (Committee on Economic Security 1937) that extensively documented European UI programs, with particular emphasis on the British and German examples. Indeed, the text of this document bears witness to the spread of UI policies internationally: "Following the example of Great Britain, seven European countries established nation-wide compulsory unemployment insurance" (ibid., 5; emphasis added). This CES report, while published in 1937, draws upon staff reports written for the committee. As the committee was only in existence from June 29, 1934 to October 1, 1935, the material that this 1937 synthesis is drawn from was written during the formation of the SSA or, at the most, a few weeks after the signing of the bill (ibid., iii).

The CES produced more than 200 unpublished individual reports over the course of its work. Later organized into ten volumes and deposited in the National Archives, the Social Security Agency has made many of them available electronically (Social Security Administration n.d.). The contents of these volumes make clear the extent to which the CES was following the example of other UI programs. In volume 1 , which focused on unemployment compensation, 23 percent of the reports were primarily studies of European unemployment compensation programs. In volume 2, which focused on OAI, 17 percent of the reports focused on European state pension programs. For volume 6, which focused on social insurance programs as a whole, nearly a quarter of the reports focused on the position of agricultural workers in existing welfare states. Based on these reports, it is clear that the CES was aware of European unemployment compensation programs and concerned with the fate of agricultural workers in the emerging US welfare state.

A potential source for confusion over the CES's knowledge of foreign experience from UI might come from Treasury Secretary Morgenthau. In the middle of his testimony before the House Ways and Means Committee, Secretary Morgenthau was asked directly about the British experience (Morgantheau 1935).

Mr. REED. Mr. Secretary your views with regard to the difficulty of collecting this tax coincide with the experience of Great Britain insofar as the domestic-service class is concerned over there.

Secretary MORGENTHAU. I am sorry, Mr. Congressman, that I am not familiar with the experiences of Great Britain. I am simply pointing out what I feel is a difficulty. Perhaps we can work out some way of overcoming that difficulty.

Mr. REED. The British Government had that difficulty, exactly along the lines you mention, and those people were eliminated from the provisions of their security act.

Secretary MORGENTHAU. I do not happen to be familiar with the British experience or practice in that respect. 
Representative Reed was thus aware of the British example. Morgenthau may not have been familiar with it, but the CES broadly speaking was quite keen to learn from the experience of other countries. Morgenthau appears to have been out of the loop on the work of the CES or, for reasons unclear, decided to be less than forthright with Congress on this matter.

The most detailed examination of the British system in this period was produced by a member of the CES, Evelyn Burns, who noted the limited coverage of the early British UI system (Burns 1941). Interestingly, while agricultural workers and domestic servants were excluded from the early British program, the justification is contrary to the one used by American technical experts. Where Americans emphasized the instability of agricultural labor and domestic service, early British studies of unemployment scarcely mentioned unemployment in these sectors of the economy because they were seen as relatively stable compared to volatile changes in employment in the industrial sector (Beveridge 1909: 20).

Edwin Witte was long aware of the British experience, and deeply critical of the ways in which it resembled the dreaded "dole" instead of a proper social insurance system. In an address at the Milwaukee County League of Women Voters' Public Welfare School of Citizenship on March 2, 1928, Witte explicitly identified John R. Commons as providing the "central idea" for the Wisconsin model of UI, and proceeded then to explain at length the details of the British system, its fiscal difficulties, and the importance of drawing a distinction between UI and "the dole." He stated that "[e]lsewhere [in Europe], however, unemployment insurance and poor relief were kept distinct. Failure to do so in Great Britain caused a lot of needless trouble, which has only recently been remedied.... Despite these handicaps, the British unemployment insurance act has not worked out so very badly. This is the opinion not only of all official commissions which have studied the working of this law, but also of all British writers on the subject" (Witte 1962: 218-21).

In a 1935 article published in the Social Service Review, Witte wrote dismissively of Britain's early program: "Unemployment compensation and relief can be combined, but, as shown by England's experience from 1924-1931, the results are almost sure to be disastrous. Unemployment compensation works best when it is given as a matter of right in such limited amounts and for such limited periods as the receipts and the reserves warrant." The possibility of too rapid an expansion of the system, of a bankrupt UI system, loomed large as a possible concern and motivated Witte's reputation as a "cautious reformer" (ibid., 237; Schlabach 1969).

In the same article, Witte addresses the British example with regard to agricultural and domestic workers. "Traditionally, in this country, agriculture, domestic service, and employment 'not in the usual course of the trade, business or profession of the employer' are exempted not only from the workmen's compensation laws but from practically all labor laws. Agriculture has been exempted from the British unemployment insurance act until now, when, finally, a special compensation scheme for agricultural workers is under consideration. Inclusion of these groups of workers is difficult administratively and, for short-time and intermittent workers, is of very little value since they seldom accumulate any substantial benefit rights. Unquestionably, 
it is desirable to include commercial agriculture and large domestic establishments, but as realists we must recognize that legislative bodies will probably prefer the traditional complete exemption" (Witte 1962: 248-49). Not only then was he looking at the British example during the development of Wisconsin's law in the late 1920s, he continued to monitor the British experience and draw upon it to push the Wisconsin model during the developments of 1935 .

The Roosevelt administration had been actively engaged with British social insurance experts since taking office. Perkins recalled that, in 1933, "[t]he Rockefeller Foundation brought over two Englishmen who had worked in social insurance, Sir William Beveridge and Sir Henry Steel-Maitland. They were invited to speak before Chambers of Commerce, Rotary Clubs, Church organizations, and their discussion of the practicability of unemployment and old-age insurance did a great deal to allay the fears and doubts of the business and conservative part of the community" (Perkins 1946: 279).

International support of the New Deal did not stop in 1933, or with the mollifying of business community concerns. The CES needed to talk to people who had actually run social insurance systems before. "[The CES] borrowed from every Department; economists, analysts, lawyers, clerical and stenographic workers, statistical experts, and equipment. We had invaluable help from two world experts, made available to us through the International Labor Organization [ILO]-Andre Tixier and Oswald Stein, who had studied the operation of every system in the world" (ibid., 282). As others have noted, the ILO had a crucial role in the spread of social insurance globally (Hu and Manning 2010; Kim 2010).

Documents from the Witte archives maintained by the University of Wisconsin provide further evidence that the Wisconsin group, and Witte in particular, were watching the British example closely. As mentioned in the preceding text, a report by Andre Tixier of the ILO and R. C. Davison of the UK Ministry of Labour presents a plan for a stamp-based system of administering UI.

It was clear that the Wisconsin faction that pushed for the exclusion of agricultural and domestic workers from UI based on their assessment on other existing UI schemes but did not intend for these exclusions to be permanent. Rather, they thought that once these systems of UI were running and fiscally sound, these groups could eventually be incorporated. In 1935, Witte was already pushing for the eventual inclusion of these groups. In a CES report on UI, he wrote that "[i]t is recommended that as soon as practicable, this restriction [on agricultural and domestic workers] be removed, and that if any other type of social legislation passed by Congress provides a broader coverage, the scope of unemployment insurance should be extended to correspond" (Witte 1935). For OAI, these changes came about in 1950 (Reticker 1955). UI followed a different trajectory.

As part of his Fair Deal program, President Truman pushed for a host of social insurance legislation, such as a national health insurance program, as well as the inclusion of agricultural and domestic workers in both UI and OAI. He thought that "[ $t]$ he present coverage of the social security laws is altogether inadequate, and benefit payments are too low. One-third of our workers are not covered" (Anon 1949b). Even 
the infamous "do-nothing" 80th Congress (1947-49) advised expanded UI coverage (Anon 1949c). This moment passed with nothing being done to expand UI coverage, save for some experimentation on the state level. California, a bastion of industrial agriculture, expanded UI to some agricultural workers, New York included domestic servants in households that employed four or more servants, and Puerto Rico and Hawaii developed schemes specifically for sugarcane workers (Anon 1949a; Hitch 1958; Witte 1951).

In the fall of 1976, agricultural and domestic workers were incorporated into the UI system with little fanfare. Coverage of the inclusion was buried at the end of a legislative roundup on page 7 of the New York Times (Lyons 1976). For 41 years, UI had operated without these groups. Over those four decades America had transitioned from a largely agricultural society, with an administratively weak government and substantial sections of its population trapped in the cashless serfdom of sharecropping to an overwhelmingly urban, industrial nation with less than 3.5 percent of its civilian labor force working in the agricultural sector (Anon 1976).

As with the exclusion of agricultural worker and domestic servants, the United States appears mainly to be following the lead of other nations in the inclusion of these groups. Table 4, drawn from Social Security Programs throughout the World, shows that no programs prior to 1935 included both agricultural workers and domestic servants. Many UI programs after 1935 included categorical exclusions of small firms, family workers, and the self-employed that would have largely excluded these groups as well. It is not until the 1970s that these workers become explicitly covered by national UI schemes. The only UI programs that appear to be universal from the outset are those originating in eastern Europe and the former Soviet Union in the early 1990s during the transition to capitalism.

\section{Limitations}

The limitations of this project are similar to the limitations of any historical project. The historical record is always incomplete, the researcher's access to the existing historical record is imperfect, and voices from the past do not exist solely to answer contemporary questions. Those who took part in making these decisions are dead. The work of the CES is closer in time to the US Civil War than the present. Historical research, like all research, is an exercise in data reduction, in presenting a limited amount of relevant information. Unlike other forms of research, no new data can be generated. Existing data can only be recombined in ways that better elucidate the past and its consequences for the present.

One of the findings presented in this article is that no compulsory UI program explicitly included agricultural workers and domestic servants at the beginning of the program until the early 1990s (table 4). Prior to the introduction of the US program, no existing UI program included these two groups of workers at all (table 3). It could be argued that if there is no variation in the exclusion of agricultural workers and domestic servants from UI, if there is no variation on the "dependent variable," there 
TABLE 4. Unemployment insurance coverage and expansion

\begin{tabular}{|c|c|c|c|c|c|c|c|c|}
\hline $\begin{array}{l}\text { Time } \\
\text { Period }\end{array}$ & Country & $\begin{array}{l}\text { Date of } \\
\text { First } \\
\text { Law }\end{array}$ & $\begin{array}{l}\text { Date of } \\
\text { Current } \\
\text { Law }\end{array}$ & $\begin{array}{l}\text { Explicit } \\
\text { Exclusion of } \\
\text { Agricultural } \\
\text { Workers at } \\
\text { Beginning of } \\
\text { Program }\end{array}$ & $\begin{array}{l}\text { Year of } \\
\text { Agricultural } \\
\text { Inclusion }\end{array}$ & $\begin{array}{l}\text { Explicit } \\
\text { Exclusion of } \\
\text { Domestic } \\
\text { Workers from } \\
\text { Beginning of } \\
\text { Program }\end{array}$ & $\begin{array}{l}\text { Year of } \\
\text { Domestic } \\
\text { Servant } \\
\text { Inclusion }\end{array}$ & $\begin{array}{l}\text { Other } \\
\text { Exclusions }^{\mathrm{a}}\end{array}$ \\
\hline \multicolumn{9}{|c|}{ Pre-1935 } \\
\hline & Austria & 1920 & 1977 & Yes & Pre-1958 & Yes & Pre-1958 & Yes \\
\hline & Bulgaria & 1925 & 2002 & No & - & Yes & Pre-1958 & Yes \\
\hline & Germany & 1927 & 2010 & Yes & 1973 & Yes & Pre- 1958 & Yes \\
\hline & Ireland & 1911 & 2005 & Yes & 1973 & Yes & 1973 & Yes \\
\hline & Italy & 1919 & 2009 & Yes & Pre-1958 & Yes & 1975 & Yes \\
\hline & $\begin{array}{l}\text { Switzerland (in } \\
\text { some cantons) }\end{array}$ & 1924 & 1998 & Yes & 1976 & Yes & 1976 & Yes \\
\hline & United Kingdom & 1911 & 1995 & Yes & 1935 & Yes & 1935 & Yes \\
\hline & United States & 1935 & 1935 & Yes & & Yes & 1977 & Yes \\
\hline \multicolumn{9}{|c|}{ 1936-90 } \\
\hline & Argentina & 1967 & 2004 & Yes & 1991 & Yes & & Yes \\
\hline & Barbados & 1982 & 1982 & No & & No & & Yes \\
\hline & Brazil & 1965 & 1991 & Yes & 1971 & Yes & 1971 & Yes \\
\hline & Canada & 1940 & 1996 & Yes & 1971 & Yes & 1971 & Yes \\
\hline & Chile & 1937 & 2009 & No & 1983 & No & 1983 & Yes \\
\hline & Croatia & 1952 & 2009 & No & & No & & Yes \\
\hline & Cyprus & 1956 & 2010 & No & & No & & Yes \\
\hline & East Germany & 1947 & 1947 & No & & No & & No \\
\hline & Egypt & 1959 & 1875 & Yes & 2012 & Yes & & Yes \\
\hline & France & 1969 & 2009 & Yes & 1974 & Yes & 1997 & Yes \\
\hline & Ghana & 1972 & $\begin{array}{l}\text { Ended in } \\
\quad \text { late 1970s }\end{array}$ & No & & No & & Yes \\
\hline & Greece & 1945 & 1990 & Yes & 1964 & Yes & 1964 & Yes \\
\hline & Guernsey & 1964 & 1978 & No & & No & & Yes \\
\hline & Iceland & 1936 & 2006 & No & & No & & Yes \\
\hline & India & 1948 & 2005 & No & & No & & Yes \\
\hline & Iran & 1987 & 1990 & No & & No & & Yes \\
\hline & Isle of Man & 1948 & 1995 & No & & No & & Yes \\
\hline & Israel & 1970 & 1973 & No & & No & & Yes \\
\hline & Japan & 1947 & 1974 & Yes & 1974 & Yes & 1974 & Yes \\
\hline & Jordan & 1978 & 2011 & No & & No & & Yes \\
\hline & Libya & 1973 & 1973 & No & & Yes & & Yes \\
\hline & Liechtenstein & 1969 & 2010 & Yes & unknown & Yes & unknown & Yes \\
\hline & Malta & 1965 & 1987 & No & & No & & Yes \\
\hline & Mauritius & 1983 & 2008 & No & & No & & Yes \\
\hline & Norway & 1959 & 1997 & Yes & 1973 & Yes & 1973 & Yes \\
\hline & Portugal & 1975 & 2010 & No & & Yes & 2010 & Yes \\
\hline & San Marino & 1967 & 2010 & No & & No & & Yes \\
\hline & South Africa & 1937 & 2002 & Yes & 1997 & Yes & 2002 & Yes \\
\hline & Spain & 1954 & 1994 & Yes & 1975 & No & & Yes \\
\hline & Taiwan & 1968 & 2003 & No & & No & & Yes \\
\hline & Uruguay & 1944 & 1981 & Yes & 2011 & Yes & 2011 & Yes \\
\hline & Venezuela & 1989 & 2012 & Yes & 2011 & Yes & 2011 & Yes \\
\hline & Vietnam & 2006 & 2009 & No & & No & & Yes \\
\hline & Yugoslavia & 1952 & $\begin{array}{l}\text { Repealed after } \\
\quad 1965\end{array}$ & No & & No & & No \\
\hline
\end{tabular}

a


TABLE 4. Continued

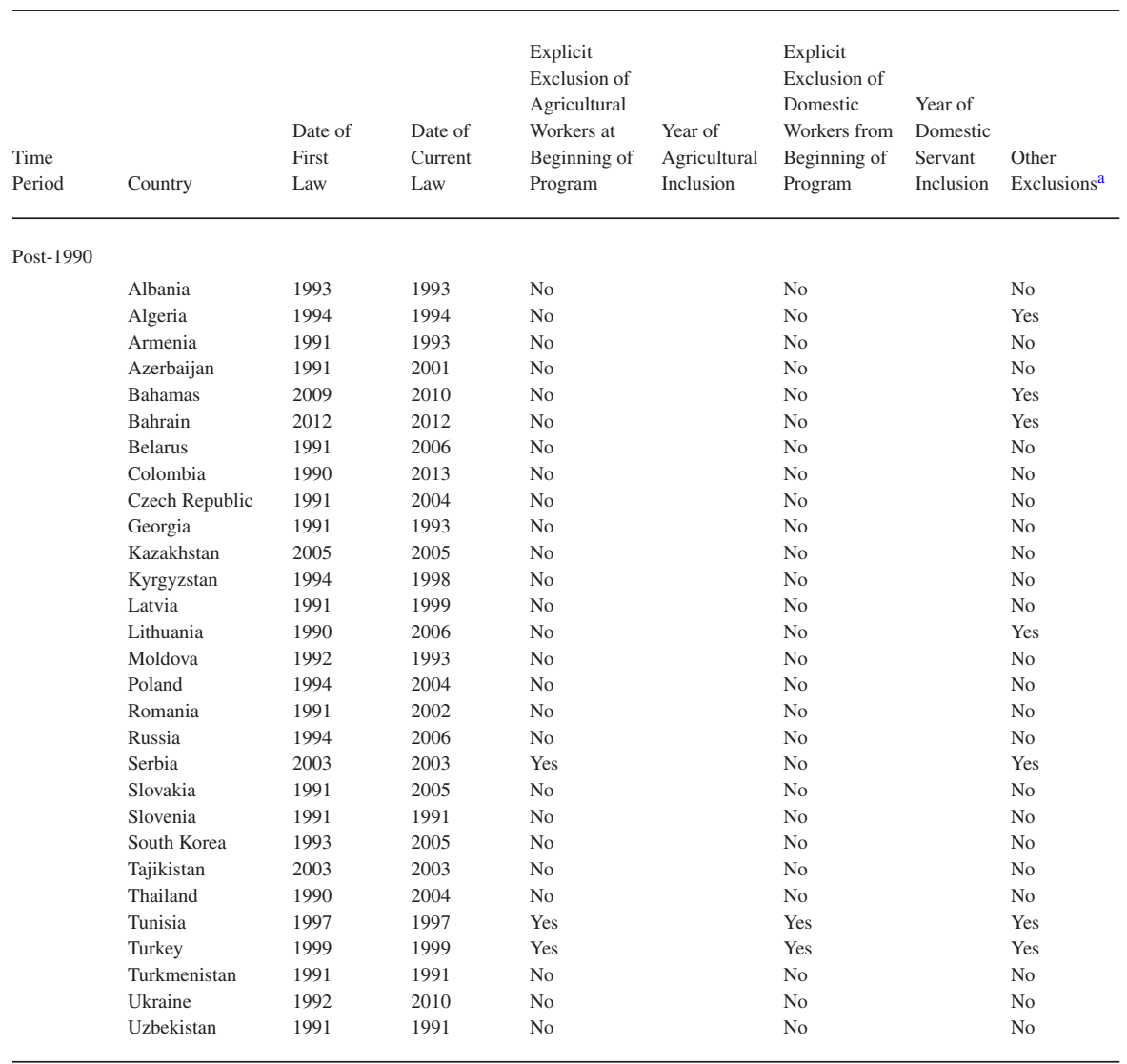

Source: Social Security Administration (1937-2000) and Social Security Administration and International Social Security Association (2002-2014).

${ }^{a}$ Exclusions of other groups based on industry, type of employment, size of firm, or sector of the economy but not concerned with exclusions based on age, residency requirements, or citizenship status. These exclusions may also capture workers at the margins of the labor market such as agricultural workers and domestic servants.

may not be a research question here at all. If this project attempted to use statistical methods common across the social sciences to assess the relationship between a set of independent and dependent variables, this would indeed be an issue.

For more than a century, social scientists engaging in macrolevel comparisons across societies have recognized a significant challenge to their research: some social phenomena are widespread and it can be difficult to assess whether or not these common phenomena are the result of parallel independent development or the result of the diffusions of social practices. Much of this article shows how the development of the American UI program was done in conversation with other existing UI programs 
and is thus not an independent observation, but rather part of a broad international social and technocratic movement. If these observations are not independent, they are poor candidates for many conventional statistical analyses. What we have not disproven is the possibility of some inherent necessity in UI programs that requires technocratic experts to limit coverage in consistent ways. Conventional variable-based methods can account for variation in a variable of interest, but they cannot illuminate the "black box" of social mechanisms that link variables together. It is precisely this sort of account that is presented in the preceding text. For a broader discussion on the difficulty of using conventional quantitative methods in macrocomparative analysis, see Goldthorpe (1997) and Abbott (1988).

\section{Conclusion}

In no way is this article meant to argue that race was an insignificant factor in the development of the American welfare state, generally, or in the passage of the SSA of 1935, more specifically. This article only seeks to shed light on one small yet consequential question: Why were agricultural workers and domestic servants excluded from UI in the 1935 SSA? This seemingly small decision contributed to the creation of a racially stratified welfare state in the United States. Explanations of this exclusion that rely upon understanding the decision solely through the prism of race miss other significant factors that point to the power of the CES to limit the scope of policy options. The exclusion of black workers from UI in the United States represents a historically contingent event, the intersection of two separate path dependent processes: (1) the legacy of white supremacy and state-sanctioned racism in the United States that had already pushed black workers to the margins of the labor market, namely agricultural labor and domestic service; and (2) the development of European social insurance programs that produced an administratively cautious, trans-Atlantic cadre of social insurance experts. These separate processes collided in the details of the new social policies advanced by the CES. By failing to adequately adjust European social insurance policy to the racial realities of US society, the CES assisted in the reproduction of the existing racial power structure in the new welfare state.

The current analysis is the first to emphasize an international, comparative perspective and the role of the Wisconsin faction of the CES, and, by doing so, we hope to begin to address the gap in international comparative interpretations of the New Deal identified by Manza (2000). The ties between Edwin Witte, Wilbur Cohen, Evelyn Burns, William Beveridge, Henry Steel-Maitland, and R.C. Davison of the Ministry of Labor, and Andre Tixier and the ILO, all point to the existence of a mutually acknowledged community of experts in the technical aspects of drafting and administering social insurance systems. Social insurance then was, in part, an elite movement requiring the utmost bureaucratic and social scientific skill and expertise. Further exploration of the size and scope of this network, as well as their beliefs and motivations remains to be done. The social insurance programs of the United States were not produced in isolation, rather the technical experts tasked with 
devising them were consciously and continuously looking for international guidance and applying the lessons of other systems in cautious, conservative ways. To examine the development of the US welfare state from a wholly domestic perspective smacks of "methodological nationalism" (Obinger et al. 2013: 118).

The implications of this process by which well-meaning reformers can unknowingly unleash such widespread economic violence are of particular concern for social policy experts today. As "evidence-based" and "replicability" become the watchwords of policy experts, and as new social policies such as conditional cash transfers spread around the globe, policy analysts and policy makers need to remember that they are not the first to engage in such activities. The welfare state is, in part, a global process of information exchange among policy elites and has been for at least a century.

\section{Acknowledgments}

The authors extend their thanks to the anonymous reviewers for their insightful comments and to Howard Kimeldorf, Kiyoteru Tsutsui, and Müge Göçek for their helpful feedback on earlier versions of this project.

\section{References}

Abbott, Andrew Delano (1988) “Transcending general linear reality.” Sociological Theory 6 (2): 169-86. Abbott, Andrew Delano, and Stanley DeViney (1992) "The welfare state as transnational event: Evidence from sequences of policy adoption.” Social Science History 16 (2): 245-74.

Achenbaum, W. A. (2007) "The segregated origins of social security: African Americans and the welfare state." Journal of Social History 41 (1): 207-8.

Altmeyer, Arthur (1945a) "Social security for domestic employees." Social Security Bulletin 8 (1): 10-11. (1945b) "Social security for “industrialized' agriculture." Social Security Bulletin 8 (3): 2-5.

Amenta, Edwin, Chris Bonastia, and Neal Caren (2001) "US social policy in comparative and historical perspective: Concepts, images, arguments, and research strategies." Annual Review of Sociology 27 (1): 213-34.

Amenta, Edwin, Elisabeth S. Clemens, Jefren Olsen, Sunita Parikh, and Theda Skocpol (1987) "The political origins of unemployment insurance in five American states." Studies in American Political Development 2: 137-82.

Anonymous (1949a) "Coverage of agricultural workers under unemployment insurance." Social Security Bulletin 12 (4): 21, 32.

(1949b) "Social security recommendations: Excerpts from the president's messages." Social Security Bulletin 12 (1): 11, 20.

(1949c) "Unemployment insurance: Recommendations of the Senate Advisory Council." Social Security Bulletin 12 (1): 12-20.

(1976) “Current labor statistics.” Monthly Labor Review: 61-99.

Benson, David, and Andrew Jordan (2011) "What have we learned from policy transfer research? Dolowitz and Marsh revisited: Learning from policy transfer research.” Political Studies Review 9 (3): 366-78.

Beveridge, William Henry (1909) Unemployment: A Problem of Industry. London: Longmans, Green, and Co.

Blaustein, Saul J., and Isabel Craig (1977) An International Review of Unemployment Insurance Schemes. Kalamazoo: The W. E. Upjohn Institute for Employment Research. 
Blaustein, Saul J., Wilbur J. Cohen, and William Haber (1993) Unemployment Insurance in the United States: The First Half Century. Kalamazoo: W. E. Upjohn Institute for Employment Research.

Brady, David (2009) Rich Democracies, Poor People: How Politics Explain Poverty. Oxford and New York: Oxford University Press.

Burns, Eveline M. (1941) British Unemployment Programs, 1920-1938. Washington, DC: Committee on Social Security, Social Science Research Council.

Clemens, Elisabeth Stephanie (1997) The People's Lobby: Organizational Innovation and the Rise of Interest Group Politics in the United States, 1890-1925. Chicago: University of Chicago Press.

Cohen, Wilbur J. (1940) Unemployment Insurance and Agricultural Labor in Great Britain. Washington, DC: Committee on Social Security of the Social Science Research Council.

Collier, David, and Richard E. Messick (1975) "Prerequisites versus diffusion: Testing alternative explanations of social security adoption." The American Political Science Review 69 (4): 1299-315.

Committee on Economic Security (1937) Social Security in America: The Factual Background of the Social Security Act as Summarized from Staff Reports to the Committee on Economic Security. Washington, DC: Social Security Board.

Davies, Gareth, and Martha Derthick (1997) "Race and social welfare policy: The Social Security Act of 1935.” Political Science Quarterly 112 (2): 217-35.

DeWitt, Larry (2010) "The decision to exclude agricultural and domestic workers from the 1935 Social Security Act." Social Security Bulletin 70 (4): 49-68.

DiMaggio, Paul J., and Walter W. Powell (1983) "The iron cage revisited: Institutional isomorphism and collective rationality in organizational fields.” American Sociological Review 48 (2): 147-60.

Dobbin, Frank, Beth Simmons, and Geoffrey Garrett (2007) "The global diffusion of public policies: Social construction, coercion, competition, or learning?" Annual Review of Sociology 33 (1): 449-72.

Dolowitz, David, and David Marsh (1996) "Who learns what from whom: A review of the policy transfer literature.” Political Studies 44 (2): 343-57.

Doughton, Robert (1935) A Bill to Alleviate the Hazards of Old Age, Unemployment, Illness, and Dependency; to Establish a Social Insurance Board in the Department of Labor, to Raise Revenue, and for Other Purposes. http://www.ssa.gov/history/pdf/fdrbill.pdf (accessed July 17, 2014).

Duranty, Walter (1930) “Soviet Will Draft All Unemployed.” New York Times, October 12.

Epstein, Abraham (1935) Statement of Abraham Epstein, Executive Secretary, American Association for Social Security, New York City. Washington, DC: Ways and Means Committee. http://www.ssa.gov/ history/pdf/hr35epstein.pdf (accessed July 17, 2014).

Esping-Andersen, Gøsta (1990) The Three Worlds of Welfare Capitalism. Cambridge: Polity Press.

Gilardi, Fabrizio (2010) "Who learns from what in policy diffusion processes?" American Journal of Political Science 54 (3): 650-66.

Goldthorpe, John H. (1997) "Current issues in comparative macrosociology: A debate on methodological issues." Comparative Social Research 16: 1-26.

Green, William (1935) "Testimony of William Green, President of the American Federation of Labor, before the House of Representatives." http://www.ssa.gov/history/pdf/hr35afl.pdf (accessed July 17, 2014).

Harrington, Michael (1998) "Trade and social insurance: The development of national unemployment insurance in advanced industrial democracies." PhD diss., University of California, Los Angeles.

Hitch, Thomas K. (1958) "Unemployment insurance for agricultural workers in Hawaii." Industrial and Labor Relations Review 11 (4): 608-14.

Hu, Aiqun, and Patrick Manning (2010) "The global social insurance movement since the 1880s." Journal of Global History 5 (1): 125-48.

International Labour Office (1955) Unemployment Insurance Schemes. London: Staples Press Limited.

Katznelson, Ira (2005) When Affirmative Action Was White: An Untold History of Racial Inequality in Twentieth-Century America. New York: W. W. Norton.

Key, V. O. (1950) Southern Politics in State and Nation. New York: Alfred A. Knopf. 
Kim, Wonik (2008) "Enfranchisement and the welfare state: Institutional design of unemployment compensation." The Journal of Socio-Economics 37 (4): 1660-78.

(2010) "The ratification of ILO conventions and the provision of unemployment benefits: An empirical analysis." International Social Security Review 63 (1): 37-55.

Lieberman, Robert C. (1998) Shifting the Color Line: Race and the American Welfare State. Cambridge, MA: Harvard University Press.

(2003) "Race and the limits of solidarity," in Sanford F. Schram, Joe Soss, and Richard C. Fording (eds.) Race and the Politics of Welfare Reform. Ann Arbor: University of Michigan Press: 23-46.

Lyons, Richard D. (1976) "Congress adjourns after delays; Clean Air Bill dies in filibuster." New York Times, October 2.

Manza, Jeff (1995) "Policy experts and political change during the New Deal." PhD diss., University of California, Berkeley.

(2000) "Political sociological models of the U.S. New Deal." Annual Review of Sociology 26 (1): 297-322.

Morgantheau, Henry (1935) "Testimony of Henry Morgantheau before the House Ways and Means Committee." http://www.ssa.gov/history/pdf/hr35morgenaja.pdf (accessed July 17, 2014).

Obinger, Herbert, Carina Schmitt, and Peter Starke (2013) "Policy diffusion and policy transfer in comparative welfare state research." Social Policy and Administration 47 (1): 111-29.

Perkins, Frances (1946) The Roosevelt I Knew. New York: Viking.

Poole, Mary (2006) The Segregated Origins of Social Security: African Americans and the Welfare State. Chapel Hill: University of North Carolina Press.

Quadagno, Jill S. (1988) The Transformation of Old Age Security: Class and Politics in the American Welfare State. Chicago: University of Chicago Press.

(1996) The Color of Welfare: How Racism Undermined the War on Poverty. New York: Oxford University Press.

Reticker, Ruth (1955) “Twenty years of unemployment insurance." Social Security Bulletin 18 (12): 3-10.

Rodgers, Daniel T. (1998) Atlantic Crossings. Cambridge, MA: Belknap Press of Harvard University Press. http://0-hdl.handle.net.biblio.eui.eu/2027/heb.00064 (accessed December 12, 2012).

Schlabach, Theron (1969) Edwin E. Witte: Cautious Reformer. Madison: State Historical Society of Wisconsin.

Skocpol, Theda (1992) Protecting Soldiers and Mothers: The Political Origins of Social Policy in the United States. Cambridge, MA: Belknap Press of Harvard University Press.

Social Security Administration (1937-2000) Social Security Programs throughout the World. Washington, DC: US Government Printing Office.

(n.d.) "Unpublished CES studies." http://www.ssa.gov/history/reports/ces/ces10vol.html (accessed July 17, 2014).

Social Security Administration and International Social Security Association (2002-2014) Social Security Programs throughout the World. https://www.ssa.gov/policy/docs/progdesc/ssptw/index.html (accessed July 17, 2014).

Tixier, Pierre A., and R. C. Davison (1936) "Suggestions on the administration of the Social Security Act and State Unemployment Compensation Law." Box 249, Edwin Witte Papers. Madison: Wisconsin Historical Society.

Witte, Edwin (1935) "Unemployment Compensation," in Reports of the Committee on Economic Security, Vol. 1, Section IV, Box 71, Edwin Witte Papers. Madison: Wisconsin Historical Society.

(1951) Five Lectures on Social Security. Rio Piedras, Puerto Rico: Labor Relations Institute, College of Social Sciences, University of Puerto Rico.

(1962) Social Security Perspectives. Madison: University of Wisconsin Press.

Zelizer, Julian E. (2004) On Capitol Hill: The Struggle to Reform Congress and Its Consequences, 19482000. Cambridge and New York: Cambridge University Press. 